\title{
РОССЫПИ ЖЕЛЕЗОСОДЕРЖАЩИХ МИНЕРАЛОВ В САХАЛИНСКОЙ ОБЛАСТИ
}

\author{
Мелкий Вячеслав Анатольевич', \\ vamelkiy@mail.ru
}

\author{
Верхотуров Алексей Александрович', \\ ussr-91@mail.ru
}

\author{
' Сахалинский государственный университет, \\ Россия, 693023, г. Южно-Сахалинск, ул. Пограничная, 2.
}

Ю.А. Билибин неоднократно подчеркивал, что для того, чтобы понять картину образования россыпей, необходимо учитывать
полный цикл их превращений. Много внимания было уделено в последнее время проблемам поиска древних погребенных рос-
сыпей и россыпей сложного строения. Богатые резервы полезных ископаемых в россыпях объясняются множественностью их ге-
нетических типов, позволяющих вовлекать в промышленную эксплуатацию новые месторождения. Актуальность работы обусловлена необходимостью выявления новых источников получения железа, титана и ванадия в условиях сокращения ресурсов минерально-сырьевой базы. Поисковые работы, выполняемые с целью выявления россыпей, наиболее перспективных для разработки, могут проводиться на основании понимания генезиса их формирования.

Цель работы: исследование закономерностей распространения россыпей железистых минералов в пределах Сахалинской области, выявление петрогенетических особенностей преобладающих минералов, определение перспектив освоения месторождений железосодержащего сырья, оценка экономической целесообразности его добычи.

Методы. Исследованы железо-титан-оксидные минералы из различных по кремнекислотности горных пород островодужных вулканогенных комплексов Большой Курильской гряды. Для исследований были подготовлены шлифы горных пород, отобрана магнитная фракция из протолочек. Шлифы пород изучались под поляризационным микроскопом. Порошок протолочек горных пород и мономинеральных фракций исследовался посредством химических аналитических методов (гравиметрического, титрометрического, спектрофотометрического, рентгенофлуоресцентного, масс-спектрометрического с индуктивно-связанной плазмой).

Результаты. Исследованы закономерности формировании железистых россыпей и определены их основные типы. На побережьях Дальнего Востока России встречаются два типа россыпей с различными условиями питания. Одна из них - Курило-Камчатская провинция собственно титаномагнетитовых россыпей - расположена на территории Сахалинской области. На островах Курильской дуги преобладают современные пляжевые россыпи и дюнные отложения низкой террасы. Главная роль в обеспечении минералами россыпей этого типа принадлежит туфопесчаникам, пемзам и пемзово-шлаковым пирокластическим толщам. Кристаллы железосодержащих минералов в горных породах вулканогенных комплексов имеют довольно разнообразные размеры: от мелких, пылеватых до крупных хорошо выраженных кристаллов, размерами более 1-2 мм. Химический состав титаномагнетитов различных вулканических комплексов изменяется в зависимости от кремнекислотности пород. Продуктивные породы характеризуются повышенным содержанием железа, титана и ванадия. Прибрежно-морские, а также древние погребенные россыпи содержат значительные объемы железосодержащих минералов. Изучение технологических схем переработки железосодержащего минерального сырья показало, что некоторые из них позволят провести его переработку с получением востребованных конечных продуктов. При определенных экономических условиях разработка россыпей может быть целесообразной.

\section{Ключевые слова:}

Металлические полезные ископаемые, титаномагнетитовые россыпи, континентальная окраина, Сахалинская область, петрогенезис, железистые минералы, титан, ванадий, акцессорные элементы-примеси, экономическая эффективность.

\section{Введение}

Практически все железосодержащие минералы (за исключением гидроокислов) обладают повышенной плотностью, а потому способны накапливаться в россыпях [1]. Эти минералы зачастую составляют основную массу «черного шлиха» (например, пирит и гематит, магнетит в золотых россыпях, магнетит и перовскит в редкометалльных россыпях карбонатитового комплекса, магнетит и титаномагнетит во многих комплексных прибрежноморских россыпях). При этом только титаномагнетит может рассматриваться в качестве ведущего россыпеобразующего минерала, формирующего самостоятельные промышленные месторождения.

Титаномагнетитовые россыпи, или так называемые «железистые пески», за редким исключением, относятся к прибрежно-морским россыпям (ПМР), которые отличаются относительной однородностью и простотой минерального состава. В иностранной геологической литературе для них часто применяется термин «черные пески», хотя иногда он употребляется и для обозначения всех типов темных песков вулканического происхождения. Железистые пески стали широко известны в $\mathrm{XIX}$ в. в связи с добычей из них золота [2].

Промышленным минералом железистых россыпей является титаномагнетит - комплексное сырье на железо и титан; полезную примесь в титаномагнетитах ПМР составляет также ванадий [3]. В связи с наличием технологических сложностей извлечения титана из титаномагнетитовых концентратов россыпей из них, в первую очередь, получают железо и ванадий.

Распространение россыпных месторождений железистых песков

Наиболее крупные и лучше всего изученные месторождения железистых песков расположены 
в Новой Зеландии (Уонгануи, Мокау). При этом около 98 \% их потенциальных запасов сосредоточено в отмелях и в дюнах западного побережья Сeверного острова на участке Уонгануи-Муривэй. Запасы отдельных россыпей превышают 200-250 млн т рудного концентрата при среднем содержании в нем до 70 \% титаномагнетита.

Другая, менее богатая, провинция развития отложений с содержанием в железо-титан-оксидах железа 23-60 \% и диоксида титана - 10-12 \% находится в Японии, на берегах Хонсю (Ома, Чикагава), Хоккайдо (р-н Саппоро), Кюсю (Фукуока) $[4,5]$. К этой группе можно отнести россыпи с высокой концентрацией минералов железа на Курильских островах и Камчатском полуострове.

Третье по значению в мире место распространения ПМР с железосодержащими химическими соединениями - Индонезия, где внушительные образования данного типа встречаются на юге Явы (Силакеп, Джокьякарта, Джампанг-Кулон), Южного Флореса, Бали, Суматры. В Океании аналогичные объекты распространены на Гибридах, Соломоновых (Ранонг и Бугенвиль) и других островах. Крупнейшие россыпи занимают прибрежную зону Филиппин - о. Лусон (более 200), более мелкие рассредоточены на Минданао, Палаване, Награсе и Лейте $[6,7]$.

Отработка титаномагнетитовых и магнетитовых ПМР периодически возобновляется в связи с добычей золота близ г. Лос-Анжелеса (США). Другие, более бедные, скопления россыпного материала известны в пределах Алеутской дуги на Кадьяке. Менее значительные залежи железо-титан-оксидных минералов обнаружены также в Карибском бассейне, в Африке - в Марокко и в Мозамбике, в Европе - в Португалии, Италии, Болгарии (г. Бургас)

\section{Общие сведения о формировании}

\section{железистых россыпей и их основных типах}

В большинстве случаев наблюдается четкая взаимосвязь железосодержащих титаномагнетитовых россыпей с вулканогенно-осадочными комплексами областей андезитового магматизма активных континентальных окраин $[8,9]$.

Железистые ПМР формируются из разрушенного пирокластического материала, выносимого реками и малыми водотоками, либо поступают непосредственно в зону пляжа в результате абразии морских берегов. В волноприбойной зоне происходит перераспределение и сепарация материала. Следующая стадия метаморфоз с отложениями - их переход в террасовые и дюнные россыпи при подъеме суши, либо в подводные - при затоплении древних береговых линий при подъеме уровня моря.

Генетическая позиция титаномагнетитовых россыпей в минералогическом плане - следствие двух факторов: а) миграционных свойств самого минерала (довольно высокая химическая стойкость и абразивная устойчивость при плотности $5-5,6$ г $\left./ \mathrm{cm}^{3}\right)$, обусловливающих возможность его концентрации в высокоэнергетических условиях волноприбойной зоны окраинных морей; б) региональной позиции коренных источников, тяготеющих к континентальным окраинам. Именно тип коренного источника определяет важнейшие черты минерального состава железистых россыпей, что подтверждается при ситовом анализе состава концентратов. В свою очередь в зависимости от минерального состава выбираются рациональные схемы обогащения россыпного материала.

В.П. Петелин выделил прибрежно-морские россыпи в качестве самостоятельного класса [10]. При этом были обособлены три типа железистых пляжевых россыпей, которые имеют разнообразные источники питания и позволяют получить концентрат определенного минерального и химического состава:

- титаномагнетитовые ванадиеносные россыпи андезитового пояса, относительно низкотитанистые (8-10\% $\mathrm{TiO}_{2}$ и до 0,5\% $\mathrm{V}_{2} \mathrm{O}_{5}$ в титаномагнетите) - месторождения Курил, Камчатки в России, Новой Зеландии, Японии.

- титаномагнетитсодержащие - смешанного комплекса - западное побережье Америки, Суматра, в России - Приморье.

- титаномагнетитовые - океанических островов, высокотитанистые (до $14 \% \mathrm{TiO}_{2}$ в титаномагнетите), с низким содержанием ванадия $\left(0,16 \% \mathrm{~V}_{2} \mathrm{O}_{5}\right)$ - острова Гавайские и Океании.

\section{Объекты исследования: титаномагнетитовые россыпи в Сахалинской области}

Наиболее обширной областью развития титаномагнетитовых россыпей в России является побережье Дальневосточных морей, где они распространены на огромной территории от Камчатки до юга Приморья. На территории Сахалинской области расположена Курило-Камчатская провинция собственно титаномагнетитовых россыпей, образованных при дезинтеграции туфогенных пород островодужного комплекса. На ее побережьях встречаются два типа россыпей с различными условиями питания. Главную роль в питании россыпей провинции играют туфопесчаники, пемзы и пемзово-шлаковые пирокластические толщи, которые наряду с лавами слагают конусы стратовулканов, а также имеют широкое распространение в виде пепловых отложений [11].

Как правило, петрографические особенности размываемых пород определяют их россыпеобразующие свойства. Так, преобладание вулканитов среднего и основного состава порфировой структуры служит надежным критерием для выделения наиболее вероятных коренных источников железистых ПМР. Тонкозернистые афанитовые разности пород также подвержены более быстрому высвобождению титаномагнетита, нежели порфировые лавы [12-14].

На о-вах Курильской дуги преобладают современные пляжевые россыпи и дюнные россыпи низкой террасы. На юге западного побережья Камчат- 
ки все россыпи связаны только с древними береговыми линиями, а на восточном побережье в питании россыпей важную роль играют промежуточные коллекторы - мощные (до 2000 м) песчано-галечные осадки аллювиального и прибрежно-морского генезиса; по данным Л.Б. Хершберга, не исключено также присутствие погребенных титаномагнетитовых ПМР.

\section{Результаты исследования и их обсуждение}

Железо-титан-оксидные минералы являются широко распространенными рудными минералами среди акцессориев в коренных источниках россыпей - породах островодужных комплексов. Среди природных оксидов выделяются минералы серий твердых растворов окислов $\mathrm{FeO}-\mathrm{Fe}_{2} \mathrm{O}_{3}-\mathrm{TiO}_{2}$ $[15,16]$. По составу Fe-Ti-оксиды разделяются на три серии: титаномагнетитовую, гемоильменитовую и псевдобрукитовую [17]. Содержание V в минералах хорошо коррелируется с содержанием Ti.

Нами были исследованы железо-титан-оксидные минералы из различных по кремнекислотности и специфике магматических пород типичных островодужных комплексов Большой Курильской гряды (БКГ).

В базальтах и андезитобазальтах раннемиоценового вулканического комплекса БКГ среди акцессориев преобладает титаномагнетит. Иногда он является существенной составляющей основной массы обломков лавобрекчий (до 4 \%). Размер зерен достигает 0,1 мм. Форма их изометричная, кубическая, ромбоэдрическая, нередки скопления зерен.

В базальтах с невысокой кремнекислотностью $\left(<50 \% \mathrm{SiO}_{2}\right)$ зерна титаномагнетитов встречаются в основной массе, форма их неправильная, размеры не превышают 150-300 мкм. С повышением кремнекислотности до 53 \% и выше кристаллы титаномагнетитов приобретают более ровные очертания и правильную изометричную форму. Состав зерен, как правило, гомогенный. Наличие структур распада отмечается в крупных изометричных зернах. Ильменитовые ламмели обычно очень редкие и тонкие (до 1 мкм). Отмечаются включения плагиоклазов в кристаллах титаномагнетита.

Железо-титан-оксиды в базальтах позднемиоценового комплекса представлены мелкими точечными выделениями титаномагнетита размером до 0,02 мм в основной массе породы, а также мелкими скелетными образованиями магнетита. В двупироксеновых базальтах кроме вкраплений титаномагнетита в основной массе отмечаются зерна размером $0,2 ? 0,3$ мм неправильной формы с неровными очертаниями. Содержание Fе-Ті-оксидных минералов в базальтах не превышает $1 \%$. С повышением кремнекислотности до $53 \%$ количество титаномагнетита увеличивается до 3-4 \%, он распространён равномерно в виде зерен размерами от 0,1 до 0,16 мм, разнообразной формы - неправильной, октаэдрической, изометричной, с зазубренными очертаниями, иногда встречаются скопления зерен и их сростки.
Железо-титан-оксидные минералы базальтов и андезитобазальтов плиоценового структурно-формационного комплекса представляет преимущественно магнетит. Кристаллы раннего магнетита в основной массе имеют изометричную, приближенную к округлой форму (размером $0,2 \times 0,4 \mathrm{mм}$ ), peже - октаэдрическую. Некоторые зерна имеют причудливо изрезанные очертания, несут следы резорбции. К ранним образованиям относятся и включения титаномагнетита в кристаллах $\mathrm{Pl}$ и Amf размером до 0,1 мм. Крупные кристаллы титаномагнетита с неровными очертаниями содержат включения $\mathrm{Pl}, \mathrm{Px}$. Часто они образуют скопления и сростки.

В пироксенах базальтов включения титаномагнетита редки, размер их не превышает 0,2 мм. Во многих образцах пироксен-плагиоклазовых базальтов ферриты-оксиды отсутствуют вовсе, иногда в основной массе наблюдаются скелетные выделения титаномагнетита. Поздние мелкозернистые зерна распространены в основной массе равномерно в отличие от крупных зерен, приуроченных к участкам с преобладанием фенокристаллов. Форма мелких зерен остроугольная, прямоугольная, ромбовидная, неправильная. Преобладают размеры от 0,01 до 0,03 мм. Иногда кристаллы образуют сростки.

Базальты плейстоцен-четвертичного вулканического комплекса наиболее распространены в Западной зоне Большой Курильской гряды. Особое внимание при изучении было уделено характерным для этой зоны базальтам вулкана Алаид, в которых железо-титан-оксидные минералы представлены преимущественно титаномагнетитом, изредка встречаются хромшпинелиды. Титаномагнетитов в основной массе содержится до 5-6 \% от объема породы. Размер их зерен не превышает 0,1 мм. Форма их преимущественно правильная, нередки скопления зерен.

В андезитах раннемиоценового комплекса титаномагнетит представлен несколькими генерациями. В цементе конгломерато-брекчий отдельные зерна размером до 0,3 мм и их скопления имеют прямоугольную, изометричную или неправильную форму, волнистые или слабо изрезанные очертания. В основной массе обломков содержатся редкие вкрапленники титаномагнетита (до 4,5-6,0%), довольно мелкие ромбовидные, изометричной формы, размером до 0,02 мм. Во вкрапленниках плагиоклаза и клинопироксена мелкие зерна титаномагнетита достигают величины 0,1 мм.

Титаномагнетиты андезитов позднемиоценового комплекса преимущественно гомогенные, имеют внутри крупных кристаллов включения Pl и Рх. Иногда это крупные и редкие включения, в некоторых случаях отмечается их приуроченность к центру зерен. Силикаты заполняют трещины в титаномагнетитах. В основной витрофировой массе андезитов магнетиты редки.

В вулканических образованиях плиоценового комплекса, отличающихся слабой дифференциро- 
ванностью и постоянством состава, титаномагнетит не имеет большого разнообразия как форм выделения, так и химического состава. Кристаллы титаномагнетита имеют ровные очертания, изометричную либо октаэдрическую форму. Состав зерен гомогенный. Пластины структур распада очень тонкие и едва различимы при увеличении в 500 раз лишь в некоторых кристаллах, что свидетельствует о хорошей сохранности кристаллов. Изредка встречаются небольшие включения силикатов.

В андезитах плиоценового комплекса титаномагнетит равномерно распределен в основной массе в мелких зернах размером до 0,1 мм. В гломеропорфировых сростках зерна титаномагнетита несколько крупнее $(0,1-0,5$ мм).

В андезитобазальтах плейстоцен-четвертичного комплекса Fе-Ті-оксиды представлены магнетитом, титаномагнетитом, изредка магнезиоферритом. Их общее количество не превышает 7 \% объема породы. Зерна довольно мелкие и не превышают размером 0,02 мм. Форма их чаще неправильная, в породе присутствует много срастаний.

В андезитах и дацитах кальдерных вулканов плейстоцен-четвертичного комплекса ферритыоксиды представлены титаномагнетитами и ильменитами. Под микроскопом наблюдается существенная неоднородность состава. Присутствуют многочисленные ильменитовые ламмели в магнетите различной толщины, в составе ильменита также присутствуют включения магнетита и гематита. Иногда наблюдаются игольчатые включения в ламмелях, представленные, по всей видимости, псевдобрукитом или рутилом. Проанализировать состав включений не удалось.

Андезиты четвертичных внутрикальдерных стратовулканов хорошо изучены на примере пород кальдеры Медвежьей. Они являются наиболее характерными представителями пород плейстоценчетвертичного комплекса в целом. Для исследования были отобраны железо-титан-оксидные минералы из образцов, любезно предоставленных В.Ф. Остапенко. Внешний облик кристаллов титаномагнетита довольно разнообразен. Форма кристаллов изменяется от неправильной до изометричной и хорошо ограненной. Кристаллы неправильной формы имеют волнистые очертания, реакционную кайму, прорастания силикатов на значительную глубину по трещинам. Во многих зернах обнаружены включения силикатов. Внутреннее строение изменяется от гомогенного до изобилующего пластинками распада различной толщины от едва различимых при больших увеличениях до очень крупных.

Формы выделения кристаллов титаномагнетита бывают разными в зависимости от различия условий охлаждения лавовых потоков. В лавовом потоке вулкана Атсонупури, вошедшем перед застыванием в воду, отмечены мелкие скелетные образования титаномагнетита.

В раннемиоценовых туфах основного и среднего состава $\mathrm{Fe}$-Ті-оксиды в основной массе встреча- ются редко, размеры их не превышают 0,25 мм в поперечнике, представлены титаномагнетитом. В некоторых зернах наблюдается срастание титаномагнетита с силикатами. Размеры отдельных зерен в скоплениях достигают 1 мм. Форма их неправильная. Иногда по периферии минералы оконтуриваются тонкой пленкой гидроокислов железа. Содержание титаномагнетита в основных и средних туфах раннемиоценового комплекса изменяется от 2 до $5 \%$. В породах отмечается несколько его разновидностей:

1) В составе эффузивного материала в базисе обломков андезитобазальтов встречаются кристаллы титаномагнетита изометричной, округлой формы с волнистыми или зазубренными очертаниями размерами $0,1-0,16$ мм. В обломках андезитов вкрапленники титаномагнетита ассоциируют с темноцветными минералами. Кристаллы в пироксене изометричны, с ровными очертаниями, часто октаэдрического габитуса, размером до 0,16 мм. Иногда вокруг зерен Рх образуются скопления титаномагнетитовых кристаллов величиной до 0,2 мм. В основной массе эффузивных обломков, как правило, распылен мелкий (размером 0,01-0,02 мм) титаномагнетит. Некоторые крупные зерна содержат мелкие (до 0,01 мм) минералы-узники плагиоклаза, реже - пироксена.

2) Среди обломков минералов в основной массе пироксены распространены меньше, чем плагиоклаз. Обычно они содержат включения титаномагнетита размером до 0,1 мм.

3) Значительное количество железо-титан-оксидных минералов наблюдается в цементирующей стекловатой массе. Преобладают мелкие (до 0,1 мм) зерна. В андезитодацитовых туфах, в цементе без какой-либо закономерности располагаются сравнительно крупные (0,2-0,3 мм) зерна титаномагнетита, иногда они образуют скопления, в некоторых случаях вокруг обломков кристаллов пироксена. Форма вкрапленников разнообразная, чаще неправильная, с волнистыми очертаниями, встречаются включения плагиоклаза и пироксена.

4) В порах и трещинах обломков пород, выполненных палагонитом или кальцитом, окаймленных свежим стеклом, наблюдаются кристаллы магнетита октаэдрического и кубического габитуса, размерами до 0,1 мм, приуроченные к зонам стеклянной оторочки.

В туфах основного и среднего состава плиоценового комплекса Fе-Ті-оксиды, естественно, имеют несколько генераций:

1) В основной стекловатой массе распространены мелкие зерна, которые концентрируются вокруг микролитов и вкрапленников Рх, образуют сростки магнетитовых зерен, а также скопления сростков.

2) В обломках кристаллов $\mathrm{Pl}$ и $\mathrm{Px}$ содержатся мелкие включения магнетита размерами до 0,02 MM. 
3) В основной массе обломков базальта содержатся крупные зерна титаномагнетита размерами до 0,25 мм.

4) В основной массе обломков андезитов содержатся мелкие (до 0,01 мм), пылеватые включения титаномагнетита.

В породах раннемиоценового комплекса нами не обнаружены самостоятельные зерна ильменитов и гематитов. Состав титаномагнетитов обычно гомогенный. Встречаемые в них пластины структур распада очень тонкие и едва различимы при увеличении в 500 раз в некоторых кристаллах.

В породах вулканических комплексов БКГ минералы гемоильменитовой серии твердых растворов окислов встречаются значительно реже, чем титаномагнетиты. Крайние члены ряда в чистом виде встречаются исключительно редко. При высоких температурах наблюдается значительная растворимость гематита и ильменита. Кроме того, при наличии даже небольшого окисления ульвошпинель быстро переходит в ильменит. Часто образуется мирмекит из магнетита и ильменита.

Во многих зернах титаномагнетита из андезитов внутрикальдерных стратовулканов наблюдаются изменения его структуры от гомогенной до изобилующей пластинками распада различной толщины - от едва различимых до очень крупных.

Ильменит встречается в породах как в виде самостоятельных зерен в основной массе, включений во вкрапленниках, так и в качестве пластинок распада твердых растворов в титаномагнетитах и имеет различный химический состав.

Гематит в вулканитах образует псевдоморфозы по магнетиту.

В андезите позднемиоценового комплекса исследовался магнетит с ильменитовыми пластинками распада. Наличие тонких ильменитовых ламмелей (до 1 мкм) также отмечено в андезитах позднемиоцен-плейстоценовой фазы вулканизма. В андезито-дацитах комплекса встречаются равномерно распределенные в витрофировой, флюидальной основной массе сферические и таблитчатые образования (до 0,06 мм) лейкоксенизированного ильменита.

Среди ферритов-оксидов в дацитах раннемиоценового комплекса преобладает титаномагнетит. Его зерна имеют ровные, реже зазубренные очертания (размер колеблется в пределах 0,08-0,25 мм). Закономерностей в распределении по объему не наблюдается. Количество железо-титан-оксидных минералов в породе не превышает 1-2 \% . В риолитах их количество увеличивается в местах скопления вкрапленников. Иногда титаномагнетиты ассоциируют с кристаллами сфена. В риодацитах мыса Столбчатого по всему объему породы равномерно распределены скопления кристаллов $\mathrm{Pl}$, Срх и титаномагнетита. По морфологии минералы в скоплениях идентичны минералам вкрапленников. Наблюдаемые скопления можно объяснить наличием кристаллизационной дифференциации магматического расплава.
Fe-Ti-оксиды в дацитах и риодацитах раннемиоценового комплекса в основном ассоциируют с темноцветными минералами и плагиоклазом. Как правило, их размеры не превышают 0,1 мм. Мелкодисперсный титаномагнетит распылен в основной массе породы.

В дацитах раннемиоценового комплекса титаномагнетиты встречаются также в виде относительно крупных (>0,4 мм) включений в пироксенах, а также очень мелко распылены в базисе породы, иногда образуют скопления. Они изобилуют тонкими пластинками структур распада.

В дацитах и риодацитах позднемиоценового комплекса размеры титаномагнетитов во вкрапленниках невелики (до 0,2 мм), а в основной массе распространена мелкая магнетитовая «сыпь».

В дацитах плейстоцен-четвертичного комплекса железо-титан-оксидные минералы представлены большим видовым разнообразием. В некоторых образцах содержится лишь небольшое количество магнетита, вкрапленного в силикатные минералы. В других, кристаллизующихся на более поздних стадиях, образуются каркасные титаномагнетиты с прорастанием ламмелей ильменита. В некоторых зернах титаномагнетита ламмели едва различимы при больших увеличениях, в других - образуют мощные прорастания, иногда включающие игольчатые включения высокотитанистых фаз твердых растворов окислов.

В дацитах и риолитах, отобранных в кальдере вулкана Головнина, пемзовых отложениях Ветрового перешейка, а также с экструзивного купола вулкана Менделеева, железо-титан-оксидные минералы представлены в основном титаномагнетитами и ильменитами. Очертания кристаллов ровные. Величина зерен 0,02-0,03 мм. Практически все титаномагнетиты кислых пород имеют гомогенный состав с крупными редкими вкрапленниками силикатов. Иногда по всему зерну распространены включения силикатов. В дацитах вулкана Головнина встречен титаномагнетит со структурами распада различной толщины.

Ильмениты были выделены для анализов также из дацитов и риолитов комплекса. Преимущественно это мелкие (до 0,06 мм), таблитчатые кристаллы, распределенные в основной массе пород.

Титаномагнетиты в кислых туфах раннемиоценового комплекса очень мелкие (менее 0,01 мм), рассредоточены преимущественно в основной массе породы. В основной массе обломков зерна титаномагнетита крупные (до 0,2 мм), гомогенные, с четкими краями, в основной массе андезитов мелкие, с тонкими пластинками структур распада, многочисленными включениями силикатов, как сферической, так и неправильной формы, с трещинами, заполненными силикатной массой.

В кислых туфах титаномагнетит часто встречается в плагиоклазах в качестве включений неправильной формы с резорбционными контурами размером 0,08×0,2 мм, а также в виде изометричной формы включений в Рх размером до 0,1 мм. В ос- 
новной массе породы форма кристаллов титаномагнетита неправильная, изометричная, размерами до 0,25 мм. Титаномагнетит, ассоциирующий с вкрапленниками плагиоклаза и пироксена в гломеропорфировых сростках, часто имеет неправильную форму.

\section{Химический состав железо-титан-оксидных минералов}

Химический состав титаномагнетитов в россыпях идентичен составу таковых в породах коренных источников россыпей (таблица). Более подробную информацию о химическом составе титаномагнетитов в породах БКГ можно получить в наших работах $[3,13,14]$.

Анализ элементов-примесей в титаномагнетитах проводился спектральным способом в лаборатории спектрально-химических методов ДВГИ ДВО РАН по методике, разработанной Т.В. Ланковой [18].

Природные хромшпинелиды, представленные твердыми растворами магнезиальных и железистых разностей хромита, шпинели, титаномагнетит и ульвошпинель, - типичные продукты эндогенного минералообразования, связанные главным образом с основными и ультраосновными породами. Они являются акцессорными минералами для большинства базальтов и некоторых более кислых пород, вплоть до гранитоидов. Будучи устойчивыми к гипергенным процессам, хромшпинелиды хорошо сохраняются в коре выветривания и могут переотлагаться в пляжевые и донные отложения $[19,20]$, которые со временем превращаются в обломочные и обломочно-осадочные породы (от гравелитов до глин). Второстепенное значение имеют хромшпинелиды в прибрежно-морских и дельтовых песках, которые на Курилах встречаются исключительно редко.

Титаномагнетиты преобладают в россыпях и составляют от 10-15 до 70-90\%, в среднем $20 \%$. Размер зерен обычно не превышает 0,25 мм. Поверхность граней минералов покрыта кавернами и выбоинами. Почти все зерна имеют тонкую оболочку из вулканического стекла толщиной в сотые и тысячные доли миллиметров.

Особенностью титаномагнетитовых минералов островодужных россыпей является присутствие в них значительного количества титана в качестве изоморфной примеси, входящей в состав кристаллической решетки. Повышенное содержание титана приводит к образованию в кристаллах титаномагнетита структур распада - ильменитовых ламелей. Самостоятельные гемоильменитовые зерна имеют пластинчатую или таблитчатую форму. Их размеры 0,1-0,2 мм.

В большинстве случаев в них содержится от 7 до $11 \% \mathrm{TiO}_{2}$. В некоторых минералах наблюдается повышенное содержание $\mathrm{Al}_{2} \mathrm{O}_{3}(8,19 \%$ в обр. 631 д) и $\mathrm{MgO}(5,26 \%$ в том же образце). Обычно содержание $\mathrm{Al}_{2} \mathrm{O}_{3}$ и $\mathrm{MgO}$ находится в пределах 1-2\%, $\mathrm{MnO}$ - от 0,5 до $1,5 \%$.
Таблииа 1. Химический состав титаномагнетитов из прибрежно-морских россыпей Большой Курильской гряды (окислы и Ті в \%, микроэлементы в г/m) [13]

Table 1. Chemical composition of titanomagnetites from coastalmarine placers of the Great Kuril ridge (oxides and $\mathrm{Ti}, \%$, trace elements, $g / t$ ) [13]

\begin{tabular}{|c|c|c|c|c|c|c|c|c|}
\hline Проба/Sample & 6326 & 632г & $626 \Gamma$ & 631д & ПІР-1 & $615 \Gamma$ & P0-9 & 634в \\
\hline $\begin{array}{l}\text { Хим. элементы } \\
\text { и оксиды } \\
\text { Elements } \\
\text { and oxides }\end{array}$ & 1 & 2 & 3 & 4 & 5 & 6 & 7 & 8 \\
\hline $\mathrm{TiO}_{2}$ & н.о. & 7,20 & н.о. & 8,19 & н.о. & 8,86 & н.о. & 11,83 \\
\hline $\mathrm{Al}_{2} \mathrm{O}_{3}$ & н.о. & 1,80 & H.о. & 1,71 & н.о. & 1,77 & н.о. & 1,29 \\
\hline $\mathrm{Fe}_{2} \mathrm{O}_{3}$ & Н.0. & 51,19 & H.о. & 44,38 & н.о. & 44,09 & н.о. & 43,71 \\
\hline $\mathrm{FeO}$ & н.о. & 36,24 & H.o. & 38,35 & H.о. & 40,75 & н.о. & 39,39 \\
\hline $\mathrm{MnO}$ & н.о. & \begin{tabular}{|l|}
0,92 \\
\end{tabular} & н.о. & 1,04 & н.о. & 0,74 & н.о. & 0,57 \\
\hline $\mathrm{MgO}$ & н.о. & 1,52 & н.о. & 5,26 & н.о. & 1,45 & н.о. & 1,37 \\
\hline $\mathrm{Cr}_{2} \mathrm{O}_{3}$ & н.о. & 0,08 & н.о. & 0,12 & н.о. & 0,04 & н.о. & 0,01 \\
\hline Сумма & & 98,95 & & 99,05 & & 97,70 & & 98,17 \\
\hline $\mathrm{Cr}$ & 140 & 250 & 100 & 300 & 48 & 93 & 76 & 300 \\
\hline $\mathrm{Mn}$ & 3500 & 4800 & 3400 & 3400 & 3400 & 4700 & 3700 & 4200 \\
\hline $\mathrm{V}$ & 2400 & 2700 & 2300 & 3000 & 2200 & 3000 & 2200 & 3500 \\
\hline $\mathrm{Ti}$ & 4,7 & 5,5 & 5,4 & 4,2 & 4,0 & 4,5 & 3,3 & 6,0 \\
\hline \begin{tabular}{|l} 
Co \\
\end{tabular} & 120 & 210 & 140 & 130 & 120 & 180 & 160 & 210 \\
\hline $\mathrm{Ni}$ & 24 & 37 & 22 & 60 & 23 & 26 & 23 & 47 \\
\hline $\mathrm{Zr}$ & 100 & 87 & 95 & 57 & 64 & 72 & 100 & 72 \\
\hline $\mathrm{Zn}$ & 630 & 910 & 910 & 480 & 480 & 500 & \begin{tabular}{|l}
370 \\
\end{tabular} & 710 \\
\hline $\mathrm{Cu}$ & 23 & 43 & 19 & 65 & 48 & 50 & 42 & 55 \\
\hline $\mathrm{Sn}$ & 30 & 50 & 21 & 26 & 14 & 25 & 21 & 50 \\
\hline
\end{tabular}

Примечание: 1 - пляж ум. Водопадного (о. Кунашир); 2 - там же; 3 - пляж севернее п. Южно-Курильск; 4 - пляж в бухте Парусной (о. Итуруп), 5 - перешеек Ветровой (о. Итуруп), 6 - севернее устья р. Серной (о. Итуруп), 7 - прибрежная россыпь рейда Открытого (о. Уруп), 8 - пляж в 300 м южне м. Четверикова (о. Кунашир). н.о. - элемент не определялся.

Additional notice: 1 - beach near Vodopadny cape (Kunashir island); 2 -ibid; 3 - beach to the north from Yuzhno-Kurilsk village; 4 - beach in the Parusnaya Bay (Iturup island), 5 - Isthmus Vetrovoy (Iturup island), 6 - to the north from mouth of the river Sernaya (Iturup island), 7 - Coastal placer of the Otkryty roadstead (Urup island), 8 -beach in $300 \mathrm{~m}$ to the south of Chetverikova cape (Kunashir island). H.o. - this element has not been defined.

По результатам спектрального химического анализа можно относительно достоверно оценивать среднее содержание микроэлементов в титаномагнетитовых россыпях. В среднем они содержат (г/т): $\mathrm{Cr}$ от 50 до 300; $\mathrm{Mn}-3400-4800 ; \mathrm{V}-$ 2200-3500; Co - 120-210; Ni - 23-60; Zr - 57-100; $\mathrm{Zn}-480-910 ; \mathrm{Cu}-23-65 ; \mathrm{Sn}-14-50$.

Химический состав минералов изменяется даже в пределах одной россыпи, особенно в отношении полезных компонентов. По данным анализа бороздовых проб, отобранных на Ручарском месторождении (о. Итуруп), содержание железа в песках колеблется от 14 до $46 \%$, двуокиси титана от 1,6 до $8 \%$, пятиокиси ванадия 0,03 до 0,08\%.

\section{Перспективы освоения месторождений сырья, содержащего железо, титан, ванадий}

В результате вулканических процессов при формировании островодужных комплексов на земную поверхность были выведены эффузивные и 
пирокластаческие породы, массовый источник титаномагнетата, Fe-Ti-V минерализации.

Нетрудно заметить, что пирокластические и эффузивные породы меловых, третичных и четвертичных вулканитов островных и окраинных поясов - исходный источник питания промежуточных коллекторов и конечных россыпей. Вулканы играют роль дробильных установок, производя туфы и туффиты, пемзы, псефиты и псаммиты. Сoдержание свободного обломочного и кристаллического сросткового титаномагнетита колеблется в них от 1 до $6 \%$.

Продуктивные породы петрохимически характеризуются повышенным содержанием железа $\left(>15 \% \mathrm{FeO}+\mathrm{Fe}_{2} \mathrm{O}_{3}\right)$, титана ( $>1 \%$ окиси титана), пятиокиси ванадия. Базальты, андезитобазальты и андезитовые лавы также содержат вкрапленный титаномагнетит гравитационной $(>0,1 \mathrm{mм})$ размерности в количествах $1-5 \%$, т. е. $25-300 \mathrm{\kappa г} / \mathrm{M}^{3}$. Абразивные клифы, вырабатываемые в таких породах трансгрессирующим морем, поставляют рудный материал для «черных песков».

Объемы вулканитов Курил, Камчатки, Охотско-Чукотского вулканического пояса составляют млн км ${ }^{3}$, и каждый км³ породы по численным оценкам заключает 50 тыс. т титаномагнетита [12].

В период с 1986 по 1994 гг. свойства железотитан-оксидных минералов Курильских островов, а также возможности их переработки изучались в лаборатории петрологии и геохимии Института морской геологии и геофизики ДВО РАН [13].

В 1992 г. Сахалинской ГРЭ проведено геологическое доизучение месторождений, в 1992-94 гг. AO «Дальморгеология» выполнены ревизионнооценочные работы с целью изучения технологических свойств песков прибрежно-морских россыпей о. Итуруп [21].

По оценке А.Г. Лапшина запасы песка категории С2 в западной части наиболее крупного Ручарскго месторождения, отнесенные к забалансовым при среднем содержании в них железа $12,83 \%$ и $\mathrm{TiO}_{2}-2,11 \%$, по действующим кондициям можно отнести к балансовым. Запасы Ручарского месторождения по песку по этим данным превысили по категориям С1 и С2 30000 тыс. т.

Суммарные запасы категории С2 Рейдовского месторождения составят, в таком случае, по пескам - 30102 тыс. т, по железу - 4 685,1 тыс. т, $\mathrm{TiO}_{2}-804,3$ тыс. т. [22].

Рейдовское месторождение (рисунок) рекомендовано для детальной разведки, Ветровое месторождение - для разведочных работ при условии вовлечения в эксплуатацию Ручарского и Рейдовского месторождений [23].

Обогащение титаномагнетитового концентрата из прибрежно-морских россыпей позволяет свести к минимуму самую дорогостоящую операцию переработки сырья - дробление - которая неизбежна

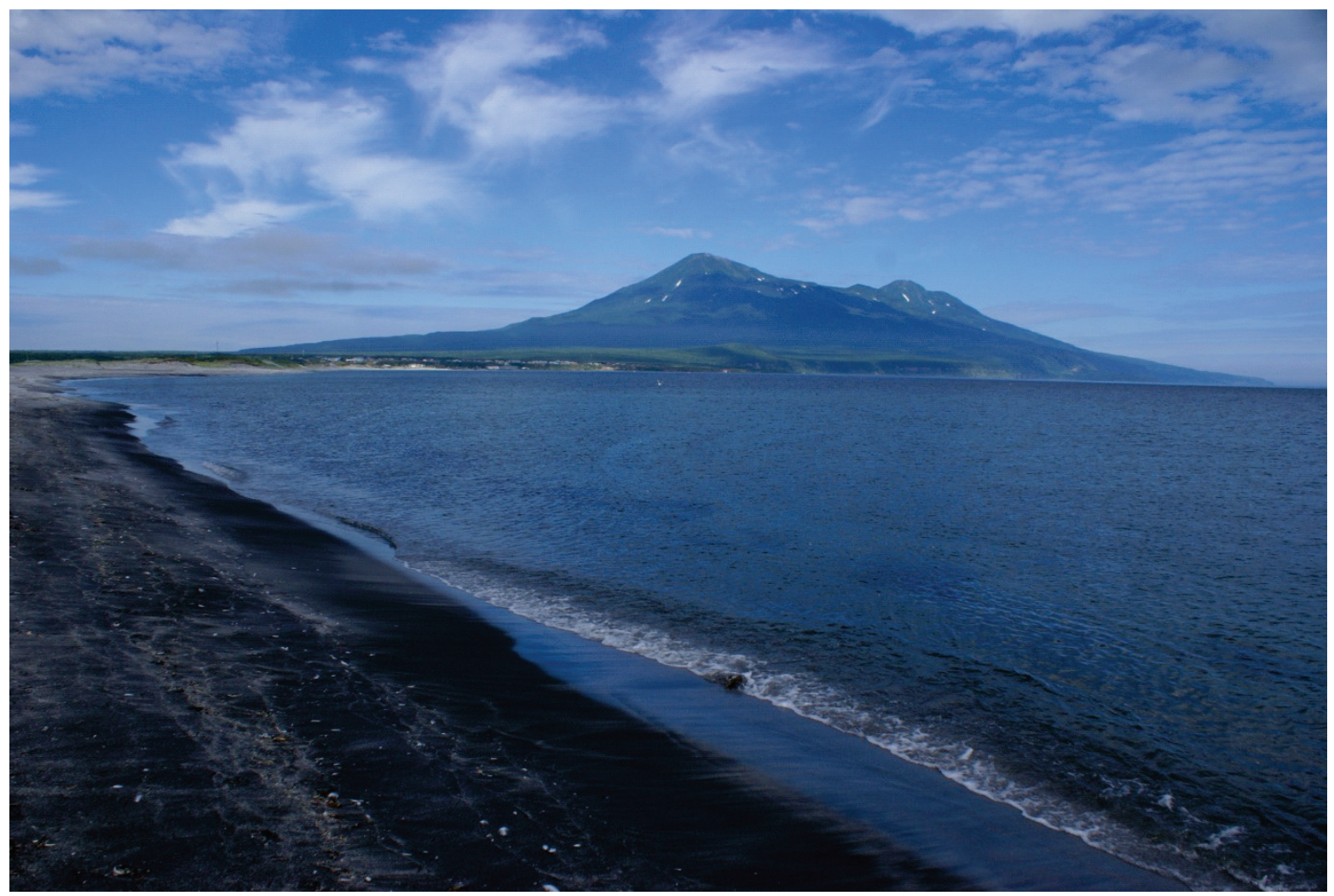

Рисунок. Пляжевая Рейдовскал россыпь. На заднем плане вулканы Богдан Хмельницкий и Чирип (о. Итуруп, Курильские острова)

Figure. Beach of Reydovskaya placer. Bohdan Khmelnytsky and Chirip volcanoes are on the background (Iturup island, Kuril Islands) 
при его извлечении из коренных пород [24, 25]. Выявлено, что дробление пород до крупности 0,074 мм приводит к тому, что производство титаномагнетитового концентрата на Качканарском ГОКе в 3-4 раза дороже добычи аналогичного концентрата на Курильских островах.

Первые технологические испытания титаномагнетитовых песков в России были проведены в 1970 г., когда в заливе Простор (о. Итуруп) была отобрана технологическая проба титаномагнетитового концентрата массой 500 т из песков с содержанием железа 8 \% . Концентрат, полученный при помощи магнитной сепарации, содержал 48,6-53,0 \% Fе и имел рабочую влажность 1,45-2,10 \% [26].

В 1993 г. в НИПИ «Уралмеханобр» под руководством Г.В. Зайцева были выполнены технологические испытания титаномагнетитовых песков с Ручарского месторождения. Был получен концентраты проб черных и серых песков с массовой долей железа - 57,8-58,1 \%, диоксида титана 10,0-10,1 \% и пентаоксида ванадия - 0,048 \% . Доизмельчение концентрата руды производилось в шаровых мельницах. Для получения однородной крупности применялись механические классификаторы. Измельченный продукт подавался на магнитные сепараторы.

В 1993 г. институтом ГИРЕДМЕТ из Ручарских песков получен титаномагнет-ильменитовый концентрат с содержанием $\mathrm{TiO}_{2}$ на уровне $23-24 \%$.

Для титаномагнетитовых концентратов могут применяться различные схемы переработки. При доменной плавке получаются шлаки с содержанием около $10 \% \mathrm{TiO}_{2}$. Ванадий переходит большей частью в чугун (до 80 \%), откуда он извлекается в шлак в конвертерах при продувке чугуна кислородом. Шлаки с содержанием 18-20\% $\mathrm{V}_{2} \mathrm{O}_{5}$ являются сырьем для производства феррованадия. Доменный передел концентратов при содержании более $4 \% \mathrm{TiO}_{2}$ образует титанистые шлаки с содержанием более $10 \% \mathrm{TiO}_{2}$, которые делаются густыми и вязкими из-за появления тугоплавких карбонитридов титана, препятствующих нормальному процессу прохождения плавки. Выходом из положения является применение шихтовки с беститанистыми концентратами магнетитовых руд, а также плавка с добавлением магнезиальных флюсов [26].

Опытные работы металлургов по переработке титаномагнетитового сырья показали, что в промышленных масштабах могут применяться следующие методы: доменный передел, одностадийная электроплавка, плавка двухстадийным методом по схеме трубчатая печь - электропечь, метод прямого восстановления железа - Крупп-Ренн процесс, а также гидрометаллургический метод извлечения ванадия [27].

Наиболее полное комплексное извлечение компонентов из концентрата возможно при прямой электроплавке, когда любое содержание титана в шлаках не оказывает негативного влияния на работу печи. Чем выше содержание титана в шлаках, тем проще и дешевле извлечение из них титана.
Ванадий при плавке переходит в чугун, из которого может быть без труда извлечен. Двухстадийный метод плавки получает все большее распространение [28, 29]. Этим методом в настоящее время перерабатываются титаномагнетитовые концентраты железистых песков в Новой Зеландии [30].

Несмотря на успешные результаты технологических испытаний титаномагнетитовых песков в «Уралмеханобре» (Екатеринбург) под руководством Г.В. Зайцева еще в 1993 г. [27], выполненную технико-экономическую оценку перспективы получения железо-ванадиевых концентратов и рекомендации по широкомасштабному освоению титаномагнетитовых россыпей, перспективы их разработки остаются еще достаточно неопределенными из-за трудностей, связанных со сложностями транспортировки продукта с Курильских островов к металлургическим комбинатам. Следует заметить, что техника и технологии переработки сырья со времени проведенных исследований ушли далеко вперед [31-39].

Испытания проб титаномагнетитовых песков Ручарского месторождения показали, что в них содержится незначительное количество редкоземельных элементов (табл. 2). Таким образом, ценность сырья увеличивается только за счет относительно высокого содержания $\mathrm{V}_{2} \mathrm{O}_{5}-0,49 \%$.

Таблица 2. Содержание редкоземельных элементов в пробах тита номагнетитовых песков Ручарского месторождения

Table 2. Content of Rare-Earth elements in Samples of titanomagnetite sands of Rucharsky deposit

\begin{tabular}{|c|c|c|}
\hline $\begin{array}{l}\text { Элемент } \\
\text { Element }\end{array}$ & $\begin{array}{l}\text { Содержание } \\
\text { Content, \% }\end{array}$ & $\begin{array}{c}\text { Метод анализа } \\
\text { Method of analysis }\end{array}$ \\
\hline Скандий/Scandium (Sc) & $0,0011-0,009$ & AES, MS \\
\hline Иттрий/Yttrium (Y) & $0,0037-0,0038$ & \multirow{15}{*}{ MS } \\
\hline Лантан/Lanthanum (La) & $0,00057-0,0006$ & \\
\hline Церий/Cerium (Ce) & $0,0018-0,0019$ & \\
\hline Празеодим/Praseodymium (Pr) & $0,0003-0,00033$ & \\
\hline Неодим/Neodymium (Nd) & $0,0019-0,0021$ & \\
\hline Самарий/Samarium (Sm) & $0,0006-0,00069$ & \\
\hline Европий/Europium (Eu) & 0,00008 & \\
\hline Гадолиний/Gadolinium (Gd) & $0,00081-0,00082$ & \\
\hline Тербий/Terbium (Tb) & 0,00013 & \\
\hline Диспрозий/Dysprosium (Dy) & $0,00072-0,00078$ & \\
\hline Гольмий/Holmium (Ho) & $0,00015-0,00016$ & \\
\hline Эрбий/Erbium (Er) & 0,00040 & \\
\hline Тулий/Thulium (TM) & 0,00006 & \\
\hline Иттербий/Ytterbium (Yb) & $0,00036-0,00042$ & \\
\hline Лютеций/Lutetium (Lu) & $0,000052-0,00006$ & \\
\hline
\end{tabular}

Примечание: Испьтания хилического состава выполнены в Аналитическом сертификационном испытательном иентре Всероссийского научно-исследовательского института минерального сырья ил. Н.М. Федоровского. Методы анализа: масс-спектральный с индуктивно-связанной плазмой (ICP-MS); атолно-элиссионный с индуктивно-связанной плазмой (ICP-AES).

Notes: Tests of Chemical composition were performed by Analytical certification test center of the All-Russian scientific-research institute of Mineral resources named after N.M. Fedorovsky. Methods of analysis: mass spectral with inductively coupled plasma (ICP-MS); atomic emission with inductively coupled plasma (ICP-AES).

Разведанные запасы месторождений на Курильских островах категорий $\mathrm{C} 1+\mathrm{C} 2$, по данным 
Сахалинской геологоразведочной экспедиции, составляют: по пескам 65552 тыс. т, общему железу - 9824 тыс. т, диоксиду титана - 1584 тыс. т, прогнозные ресурсы на 15 россыпях оцениваются по пескам в 94488 тыс. т, железу общему 13107 тыс. т, диоксиду титана - 1650 тыс. т [40]

\section{Заключение}

Основываясь на опыте формирования современного производственно-территориального комплек-

\section{СПИСОК ЛИТЕРАТУРЫ}

1. Билибин Ю.А. Основы геологии россыпей. - М.; Л.: ГОНТИ Гл. редакция горно-топлив. и геол.-развед. литературы. Тип. "Рабоч. Москва», 1938. - 505 с.

2. Stanaway K.J. Heavy Mineral Placers // Mining Engineering. 1992 April. - V. 44. - P. 352-358.

3. Россыпные месторождения России и других стран СНГ (минерагения, промышленные типы, стратегия развития минерально-сырьевой базы) / Н.Г. Патык-Кара, Б.И. Беневольский, Л.З. Быховский, Л.Б. Зубков, А.А. Кременецкий, Е.В. Матвеева, В.А. Мелкий, В.Е. Минорин, А.Г. Мочалов, Н.М. Риндзюнская, Б.В. Рыжов, Л.В. Спорыхина, Е.А. Черемисина / отв. ред. Н.П. Лавёров, Н.Г. Патык-Кара. - М.: Научный мир, 1997. $-479 \mathrm{c}$

4. Айнемер А.И., Коншин Г.И. Россыпи шельфовых зон Мирового океана. - Л.: Недра, 1982. - 263 с.

5. Kholodov V.N., Nedumov R.I., Golubovskaya E.V. Facies types of Sedimentary iron ore deposits and their geochemical features: Communication 1. Facies groups of Sedimentary ores, their Lithology, and Genesis // Lithology and Mineral Resources. 2012. - V. 47. - № 6. - P. 447-472.

6. Минералогия и геохимия россыпей / отв. ред. Н.А. Шило, Н.Г. Патык-Кара. - М.: Наука, 1992. - 246 с.

7. Патык-Кара Н.Г. Минерагения россыпей: типы россыпных провинций. - М.: Учреждение Российской академии наук Институт геологии рудных месторождений, петрографии, минералогии и геохимии (ИГЕМ РАН), 2008. - 528 с.

8. S'edin V.T., Piskunov Yu.G., Melkiy V.A. Titanium-magnetite sands of the Kuril islands // Abst. Intern. Conference on the Seas of Japan and Okhotsk (Nakhodka, Sept. 1989). - Vladivostok: Publishing house of FEB of Academy Science of the USSR, 1989. P. 76-77.

9. Мелкий В.А. Петромагнетизм пород базальтоидного вулканического комплекса острова Итуруп // Актуальные вопросы геологии, геофизики и биологии (Материалы XVI конференции молодых ученых ИМГиГ). - Южно-Сахалинск, Изд-во ИМГиГ, 1990. - С. 41-50.

10. Петелин В.П. Основные типы пляжевых концентратов тяжелых минералов бассейна Тихого океана // Океанология. 1964. - T. 4. - Вып. 6. - С. 1052-1058.

11. Павлидис Ю А. Некоторые особенности образования современных прибрежных отложений в пределах вулканического архипелага. На примере Курильских островов. - М: Наука, 1968. $112 \mathrm{c.}$

12. Кутолин В.А., Прусевич А.А. Геологические предпосылки для поисков титаномагнетитовых россыпей Татарского пролива. Новосибирск: Изд-во Института геологии и геофизики $\mathrm{CO} \mathrm{AH}$ CCCP, 1984. - 152 c.

13. Мелкий В.А. Петрогенезис железо-титан-оксидных минералов в вулканических комплексах Большой Курильской гряды // Серия «Монографии ученых «Сахалинского государственного университета»". - Южно-Сахалинск: Изд-во СахГУ, 2010. $143 \mathrm{c}$. са на территории Сахалинской области, который сложился в результате привлечения инвестиций для интенсивной разработки месторождений минерального сырья, разведанных в период масштабных комплексных исследований, можно предположить, что в ближайшей перспективе инвестирование в доразведку, совершенствование технологий обогащения и промышленной переработки позволит организовать на островах рентабельное освоение россыпей железосодержащих минералов.

14. Мелкий В.А. Петрогенетическая информативность железо-титан-оксидных минералов вулканических комплексов Большой Курильской гряды: дис.... канд. геол.-минерал. наук. - М., 1995. - $270 \mathrm{c}$.

15. Spenser K.J., Lindsley D.H. A solution model for coexisting irontitanium oxides // Amer. Miner. - 1981. - V. 66. - № 11/12. P. 1189-1202.

16. Solid-liquid phase equilibria of $\mathrm{Fe}-\mathrm{Cr}-\mathrm{Al}$ alloys and spinels / J.W. McMurray, R. Hu, S.V. Ushakov, D. Shin, A. Navrotsky // Journal of Nuclear Materials. - 2017. - V. 492. - P. 128-133.

17. Buddington A.F. Lindsley D.H. Iron-titanium oxide minerals and synthetic equivalents // Journal of Petrology. - 1964. - № 5. P. 310-357.

18. Парагенезисы микроэлементов магнетита / С.А. Щека, А.Г. Пятков, А.А. Вржосек, Г.Б. Левашев, Р.А. Октябрьский // Геохимия. - 1978. - № 5. - С. 719-728.

19. Савичев О.Г., Домаренко В.А., Перегудина Е.В., Нгуен В.Л., Шалдыбин М.В., Канаки А.В. Минералого-геохимические особенности донных отложений малых рек в междуречье рек Ло и Кау (Северный Вьетнам) // Известия Томского политехнического университета. Инжиниринг георесурсов. - 2017. T. 328. - № 9. - C. 102-113.

20. Hou B., Keeling J., Van Gosen B.S. Geological and exploration models of beach placer deposits, integrated from case-studies of Southern Australia // Ore Geology Reviews. - 2017. - № 80. P. $437-459$

21. Ревизионно-оценочные работы с целью изучения технологических свойств ильменит-магнетитовых песков итурупской группы прибрежно-морских россыпей в 1992-1994 гг. / Л.Б. Хершберг, Б.И. Вачаев, Е.М. Печникова, В.В. Хитров. Партизанск: Дальморгеология, 1994. - 62 с.

22. Полезные ископаемые Сахалинской области / Р.Н. Гордина, Н.С. Макарова, Т.С. Разорителева, Л.Ф. Тузова, А.С. Шепелев / под. ред. А.М. Меренкова, Н.В. Галушка, В.Е. Горетого, В.И. Высочина, В.В. Медведева, Т.С. Разорителевой, А.С. Чибисова, Л.М. Чумакова. - Южно-Сахалинск: Сахалинское книжное издательство, 2002. - 120 с.

23. Мелкий В.А. и др. Экспертиза готовности существующих материалов геологического и технологического характера для постановки запасов Ручарского и Рейдовского месторождений ильменит-магнетитовых песков на государственный баланс. Отчет по договору 1-01-07-05. - Новокузнецк: 0А0 «Евразруда», 2005. - 36 c.

24. Sanford L.P. Modeling a dynamically varying mixed sediment bed with erosion, deposition, bioturbation, consolidation, and armoring // Comput. Geosci. - 2008. - № 34. - P. 1263-1283.

25. Yoshikawa S., Nemoto K. The role of summer monsoon-typhoons in the formation of nearshore coarse-grained ripples, depression, and sand-ridge systems along the Shimizu coast, Suruga Bay facing the Pacific Ocean, Japan // Marine Geology. - 2014. V. $353 .-$ P. $84-98$.

26. Резниченко В.А., Шабалин Л.И. Титаномагнетиты: месторождения, металлургия, химическая технология. - М.: Наука, 1986. -295 c. 
27. Зайцев Г.В. и др. Технико-экономическая оценка технологии получения железо-ванадиевых концентратов и разработка рекомендации по снижению эксплутационных затрат. - Екатеринбург, НИПИ «Уралмеханобр», 1994. - 93 с.

28. Gupta C.K., Krishnamurthy N. Extractive metallurgy of Vanadium (Process Metallurgy). - Netherlands: Elsevier Science Publishers B.V., 1992. - 690 p.

29. Gupta C.K. Chemical Metallurgy: Principles and Practice. Weinheim: WILEY-VCH, 2003. 811 p.

30. Thomson S., Tin W. The Story of Corrugated iron in New Zealand. - Wellington: Steele Roberts, 2005. - 107 p.

31. Зайцев Г.В. Современные направления развития техники и технологии производства высококачественного железорудного концентрата с высокими технико-экономическими показателями // Стройка: Региональное издание. - 2006. - № 9. URL: http://library.stroit.ru/articles/concentrat/index.html (дата обращения: 11.03.2018).

32. Рощин В.Е., Асанов А.В., Рощин А.В. Возможности двухстадийной переработки концентратов титаномагнетитовых руд // Электрометаллургия. - 2010. - № 6.- С. 15-25.

33. Rapid selective extraction of $\mathrm{V}(\mathrm{V})$ from leaching solution using annular centrifugal contactors and stripping for $\mathrm{NH}_{4} \mathrm{VO}_{3} /$ X. Jing, J. Wang, H. Cao, P. Ning, Z. Sun // Separation and Purification Technology. - 2017. - V. 187. - P. 407-414.

34. Beneficiation studies of a difficult to treat iron ore using conventional and microwave roasting / S.S. Rath, N. Dhawan, D.S. Rao,
B. Das, B.K. Mishra // Powder Technology. - 2016. - V. 301. P. 1016-1024.

35. Смирнов Л.А., Кушнарев А.В. Современное состояние и перспективы титаномагнетитового ванадийсодержащего сырья в России / Ч Черная металлургия. - 2013. - № 5 (1361). - С. 3-21.

36. Beneficiation of an iron ore fines by magnetization roasting and magnetic separation / J. Yu, Yu. Han, Ya. Li, P. Gao // International Journal of Mineral Processing. - 10 November 2017. V. 168. - P. 102-108.

37. Asynchronous extraction of vanadium and chromium from vanadium slag by stepwise sodium roasting-water leaching / Li HongYi, Fang Hai-Xing, Wang Kang, Zhou W. et al. // Hydrometallurgy. - 2015. - V. 156. - P. 124-135.

38. Application of ferrous pyrometallurgy to the beneficiation of rare earth bearing iron ores - a review / N. Faris, R. Ram, J. Tardio, S. Bhargava, M.I. Pownceby // Minerals Engineering. 2017. - V. 110. - P. 20-30.

39. Comparative study of alkali roasting and leaching of chromite ores and titaniferous minerals / S. Parirenyatwa, L. EscuderoCastejon, S. Sanchez-Segado, Y. Hara, A. Jha - Hydrometallurgy. - 2016. - Volume 165. - Part 1. - P. 213-226.

40. Евсеев В.Ф., Речкин А.Н., Лапшин А.Г. Недра Сахалинской области / под ред. А.В. Тарасова. - Южно-Сахалинск: 000 «Изд-во Сахалин - Приамурские ведомости», 2013. - 120 с.

Поступила 18.04.2018 2.

\section{Информация об авторах}

Мелкий B.A., доктор технических наук, заведующий кафедрой геологии и нефтегазового дела, директор Технического нефтегазового института Сахалинского государственного университета.

Верхотуров A.A., кандидат технических наук, старший преподаватель кафедры геологии и нефтегазового дела Технического нефтегазового института Сахалинского государственного университета. 
UDC 550.8:552.1:502.3/.7

\title{
PLACER OF IRON-BEARING MINERALS IN THE SAKHALIN REGION
}

\author{
Vyacheslav A. Melkiy', \\ vamelkiy@mail.ru
}

\author{
Alexey A. Verkhoturov', \\ ussr-91@mail.ru \\ Sakhalin State University,
2, Pogranichnaya street, Yuzhno-Sakhalinsk, 693023, Russia.
}

Yuriy A. Bilibin has repeatedly stressed that in order to understand the picture of the formation of placers, you need to know the full cycle of their transformations. Much attention has been paid in recent years to the problems of finding ancient buried placers and placers complex structure. The rich reserves of minerals in placers are explained by the multiplicity of their genetic types, which allow involving new deposits in commercial exploitation.

The relevance of the work is caused by the need to identify new sources of iron, titanium and vanadium in terms of reducing the resources of the mineral resource base. Exploration works performed to identify placers, the most promising for development, can be carried out on the basis of the awareness of the genesis of their formation.

The main aim of the research is to study the laws of distribution patterns of placers of ferrous minerals within the Sakhalin region, identify the petrogenetic features of the prevailing minerals, define the prospects of exploration of deposits of iron-containing raw materials, assess the economic expediency of their extraction.

The methods. We have researched iron-titanium-oxide minerals from different silicic-acidic rocks of island-arc volcanogenic complexes of Great Kuril String of islands. Thin sections of samples of rock and magnetic fraction of crushed samples were prepared. The thin sections of the rocks were studied under a polarizing microscope. Crushed samples of rocks and their monomineral fractions were studied by means of chemical analytical methods (gravimetric, titrometric, spectrophotometric, $X$-ray fluorescence, mass spectrometry with inductively coupled plasma).

The results. We have completed studies of the patterns of formation of ferruginous placers and identified their main types. There are two types of placers with different conditions of alimentation zone of minerals on the coasts of the Russian Far East. One of them - Kuril-Kamchatka province of placers actually titanomagnetite - is located on the territory of the Sakhalin region. The beach placers and dune deposits of low terraces dominate on the Islands of the Kuril Arc. The tufo-sandstone, pumice, and pumice-scoria pyroclastic deposits play the main role in delivering the minerals in placers of this type. Crystals of iron-containing minerals in rocks of volcanogenic complexes have rather different sizes: from small, dusty to large well-expressed crystals, more than 1-2 mm in size. The chemical composition of titanomagnetites of different volcanic complexes varies depending on silica acidity of rocks. Productive rocks are characterized by high content of iron, titanium and vanadium. Coastal-marine, as well as ancient buried placers contain significant amounts of iron-containing minerals. Studying of technological schemes of processing of iron-containing mineral raw materials showed that some of them would allow carrying out their processing with receiving the highly sought final products. Under certain economic conditions, the development of placers may be appropriate.

\section{Key words:}

Metalic natural resources, placers of titanomagnetite, continental margin, Sakhalin region, petrogenesis, ferrous minerals, titanium, vanadium, accessory elements-impurities, economic efficiency.

\section{REFERENCES}

1. Bilibin Yu.A. Osnovy geologii rossypey [Foundations of Geology of Placers]. Moscow, Leningrad, GONTI, Working Moscow, 1938. $505 \mathrm{p}$.

2. Stanaway K.J. Heavy Mineral Placers. Mining Engineering, April 1992, vol. 44, pp. 352-358.

3. Patyk-Kara N.G., Benevolsky B.I., Bykhovsky L.Z., Zubkov L.B., Kremenetsky A.A., Matveeva E.V., Melkiy V.A., Minorin V.E., Mochalov A.G., Rindzyunskaya N.M., Ryzhov B.V., Sporykhina L.V., Cheremisina E.A. Rossypnye mestorozhdeniya Rossii $i$ drugikh stran SNG (minerageniya, promyshlennye tipy, strategiya razvitiya mineralno-syrevoy bazy) [Placer deposits of Russia and other countries of CIS (mineralogy, industrial types, strategy of development of mineral resource base)]. Eds. N.P. Laverov, N.G. Patiyk-Kara. Moscow, Nauchny mir Publ., 1997. 479 p.

4. Aynemer A.I., Konshin G.I. Rossypi shelfovykh zon Mirovogo okeana [Placers of shelf zones of World ocean]. Leningrad, Nedra Publ., 1982. $263 \mathrm{p}$

5. Kholodov V.N., Nedumov R.I., Golubovskaya E.V. Facies types of Sedimentary iron ore deposits and their Geochemical features: Communication 1. Facies groups of Sedimentary ores, their
Lithology, and Genesis. Lithology and Mineral Resources, 2012, vol. 47, no. 6, pp. 447-472.

6. Mineralogiya i geokhimiya rossypey [Mineralogy and Geochemistry of placers]. Eds. N.A. Shilo, N.G. Patyk-Kara. Moscow, Nauka Publ., 1992. 246 p.

7. Patyk-Kara N.G. Minerageniya rossypey: tipy rossypnykh provintsiy [Mineral deposits of placers: types of placer provinces.]. Moscow, Establishment of Russian Academy of Sciences Institute of Geology of Ore deposits, Petrography, Mineralogy and Geochemistry (IGEM RAS), 2008. 528 p.

8. S'edin V.T., Piskunov Yu.G., Melkiy V.A. Titanium-magnetite sands of the Kuril islands. Abst. Intern. Conference on the Seas of Japan and Okhotsk. Nakhodka, Sept. 1989. Vladivostok6 FEB of Academy Science of the USSR Publ. house, 1989. pp. 76-77.

9. Melkiy V.A. Petromagnetizm porod bazaltoidnogo vulkanicheskogo kompleksa ostrova Iturup [Petromagnetism of rocks of the basaltic volcanic complex of Iturup island]. Aktualnye voprosy geologii, geofiziki i biologii. Materialy XVI konferentsii molodykh uchenykh IMGiG [Actual problems of Geology, Geophysics and Biology. Proc. of the XVI conference of young scientists of IMGiG]. Yuzhno-Sakhalinsk, IMGiG Publ., 1990. pp. 41-50. 
10. Petelin V.P. Basic types of beach concentrates of heavy minerals of the Pacific basin. Oceanology, 1964, vol. 4, Iss. 6, pp. 1052-1058. In Rus.

11. Pavlidis Yu.A. Nekotorye osobennosti obrazovaniya sovremen nykh pribrezhnykh otlozheniy v predelakh vulkanicheskogo arkhipelaga. Na primere Kurilskikh ostrovov [Some features of formation of modern coastal sediments within the boundaries of the volcanic archipelago. On the example of the Kuril Islands]. Moscow, Nauka Publ., 1968. 112 p.

12. Kutolin V.A., Prusevich A.A. Geologicheskie predposylki dlya poiskov titanomagnetitovykh rossypey Tatarskogo proliva [Geological background for search of titanomagnetite placers of the Tatar Strait]. Novosibirsk, Institute Geology and Geophysics SB Academy Science of the USSR Publ. house, 1984. 152 p.

13. Melkiy V.A. Petrogenezis zhelezo-titan-oksidnykh mineralov $v$ vulkanicheskikh kompleksakh Bolshoy Kurilskoy gryady. Seriya «Monografii uchenykh «Sakhalinskogo gosudarstvennogo universiteta»» [Petrogenesis of iron-titanium-oxide minerals in volcanic complexes of the Great Kuril ridge. Series «Monographs of Scientists "Sakhalin State University"»]. Yuzhno-Sakhalinsk, SakhGu Publ., 2010. 143 p.

14. Melkiy V.A. Petrogeneticheskaya informativnost zhelezo-titan oksidnykh mineralov vulkanicheskikh kompleksov Bolshoy Kuril skoy gryady. Dis. Kand. nauk [Petrogenetic informativeness of iron-titanium-oxide minerals of Volcanic complexes of the Great Kuril Ridge. Cand. Diss.]. Moscow, MGU M.V. Lomonosov, 1995. $270 \mathrm{p}$.

15. Spenser K.J., Lindsley D.H. A solution model for coexisting irontitanium oxides. Amer. Miner., 1981, vol. 66, no. 11/12, pp. 1189-1202.

16. McMurray J.W., Hu R., Ushakov S.V., Shin D., Navrotsky A. Solid-liquid phase equilibria of $\mathrm{Fe}-\mathrm{Cr}-\mathrm{Al}$ alloys and spinels. Journal of Nuclear Materials, 2017, vol. 492, pp. 128-133.

17. Buddington A.F. Lindsley D.H. Iron-titanium oxide minerals and synthetic equivalents. Journal of Petrology, 1964, no. 5, pp. 310-357.

18. Shcheka S.A., Pyatkov A.G., Vrzhosek A.A., Levashev G.B., Oktyabrskiy R.A. Paragenezisy mikroelementov magnetita [Paragenesis of the trace elements in magnetite]. Geochemistry, 1978, no. 5, pp. 719-728.

19. Savichev 0.G., Domarenko V.A., Peregudina E.V., Nguyen Van Luyen, Shaldybin M.V., Kanaki A.V. Mineral geochemical features of the Minor river sediments in the interfluve area of the Lo and Kau rivers (Northern Vietnam). Bulletin of the Tomsk Polytechnic University. Geo Assets Engineering, 2017, vol. 328, no. 9. pp. 102-113. In Rus.

20. Hou B., Keeling J., Van Gosen B.S. Geological and exploration models of beach placer deposits, integrated from case-studies of Southern Australia. Ore Geology Reviews, 2017, no 80, pp. $437-459$.

21. Khershberg L.B., Vachaev B.I., Pechnikova E.M., Khitrov V.V. Revizionno-otsenochnye raboty s tselyu izucheniya tekhnologicheskikh svoystv ilmenit-magnetitovykh peskov iturupskoy gruppy pribrezhno-morskikh rossypey $v$ 1992-1994 gg. [Audit and evaluation work to study the technological properties of ilmenitemagnetite sands of the Iturup group of coastal and marine placers in 1992-1994]. Partizansk, Dalmorgeologiya Publ., 1994. 62 p.

22. Gordina R.N., Makarova N.S., Razoriteleva T.S., Tuzova L.F., Shepelev A.S. Poleznye iskopaemye Sakhalinskoy oblasti [Usefu] minerals of the Sakhalin Region]. Eds. A.M. Merenkov, N.V. Galushka, V.E. Goretoy, V.I. Vysochin, V.V. Medvedev, T.S. Razoriteleva, A.S. Chibisov, L.M. Chumakov. Yuzhno-Sakhalinsk, Sakhalin book Publ. house, 2002. 120 p.

23. Melkiy V.A. Ekspertiza gotovnosti sushchestvuyushchikh materialov geologicheskogo $i$ tekhnologicheskogo kharaktera dlya postanovki zapasov Rucharskogo i Reydovskogo mestorozhdeniy ilme nit-magnetitovykh peskov na gosudarstvenny balans [Expert exa- mination of readiness of existing case materials of geological and technological nature for production of reserves Rucharskoe and Reydovskoe deposits of ilmenite-magnetite sands on the state balance]. The agreement report 1-01-07-05. Novokuznetsk, JSC "Eurasruda», 2005. 36 p.

24. Sanford L.P. Modeling a dynamically varying mixed sediment bed with erosion, deposition, bioturbation, consolidation, and armoring. Comput. Geosci., 2008. No. 34. pp. 1263-1283.

25. Yoshikawa S., Nemoto K. The role of summer monsoon-typhoons in the formation of nearshore coarse-grained ripples, depression, and sand-ridge systems along the Shimizu coast, Suruga Bay facing the Pacific Ocean, Japan. Marine Geology, 2014, vol. 353, pp. 84-98.

26. Reznichenko V.A., Shabalin L.I. Titanomagnetity: mestorozhdeniya, metallurgiya, khimicheskaya tekhnologiya [Titanomagnetites: deposits, metallurgy, chemical engineering]. Moscow, Nauka Publ., 1986. 295 p.

27. Zaytsev G.V. Tekhniko-ekonomicheskaya otsenka tekhnologii polucheniya zhelezo-vanadievykh kontsentratov $i$ razrabotka rekomendatsii po snizheniyu eksplutatsionnykh zatrat [Technical and economic assessment of technology for producing iron-vanadium concentrates and development of recommendations to reduce operating costs]. Ekaterinburg, Uralmekhanobr Research Institute Publ., 1994. 93 p.

28. Gupta C.K., Krishnamurthy N. Extractive metallurgy of Vanadium (Process Metallurgy). Netherlands, Elsevier Science $\mathrm{Pu}-$ blishers B.V., 1992.690 p.

29. Gupta C.K. Chemical Metallurgy: Principles and Practice. Weinheim, WILEY-VCH, 2003. $811 \mathrm{p}$.

30. Thomson S., Tin W. The Story of Corrugated iron in New Zealand. Wellington, Steele Roberts, 2005. 107 p.

31. Zaytsev G. V. Sovremennye napravleniya razvitiya tekhniki $i$ tekhnologii proizvodstva vysokokachestvennogo zhelezorudnogo kontsentrata s vysokimi tekhniko-ekonomicheskimi pokazatelya$m i$ [Modern trends in developing the equipment and technologies for production of high-quality iron ore concentrate with high technical and economic reading]. Construction: Regional edition, 2006, no. 9. Available at: http://library.stroit.ru/articles/concentrat/index.html (accessed: 11 March 2018).

32. Roshchin V. E., Asanov A. V., Roshchin A. V. Possibilities of two-stage processing titanium-magnetite ore concentrates. Russian metallurgy (Metally), 2010, no. 6, pp. 15-25. In Rus.

33. Jing X., Wang J., Cao H., Ning P., Sun Z. Rapid selective extraction of $\mathrm{V}(\mathrm{V})$ from leaching solution using annular centrifugal contactors and stripping for $\mathrm{NH}_{4} \mathrm{VO}_{3}$. Separation and Purification Technology, 2017, vol. 187, pp. 407-414.

34. Rath S.S., Dhawan N., Rao D.S., Das B., Mishra B.K. Beneficiation studies of a difficult to treat iron ore using conventional and microwave roasting. Powder Technology, 2016, vol. 301, pp. 1016-1024.

35. Smirnov L.A., Kushnarev A.V. Sovremennoe sostoyanie i perspektivy titanomagnetitovogo vanadiysoderzhashchego syrya $\mathrm{v}$ Rossii [Current state and prospects of titanium-magnetite vanadium-containing raw materials in Russia]. Chernaya metallurgiya, 2013, no. 5 (1361), pp. 3-21.

36. Yu J., Han Yu., Li Ya., Gao P. Beneficiation of an iron ore fines by magnetization roasting and magnetic separation. International Journal of Mineral Processing, 10 November 2017, vol. 168, pp. 102-108.

37. Li Hong-Yi, Fang Hai-Xing, Wang Kang, Zhou W. Asynchronous extraction of vanadium and chromium from vanadium slag by stepwise sodium roasting-water leaching. Hydrometallurgy, 2015, vol. 156, pp. 124-135.

38. Faris N., Ram R., Tardio J., Bhargava S., Pownceby M.I. Application of ferrous pyrometallurgy to the beneficiation of rare earth bearing iron ores - a review. Minerals Engineering, 2017, vol. 110 , pp. 20-30. 
39. Parirenyatwa S., Escudero-Castejon L., Sanchez-Segado S., Hara Y., Jha A. Comparative study of alkali roasting and leaching of chromite ores and titaniferous minerals. Hydrometallurgy, 2016, vol. 165, P. 1, pp. 213-226.
40. Evseev V.F., Rechkin A.N., Lapshin A.G. Nedra Sakhalinskoy oblasti [Bowels of the earth of the Sakhalin region]. Ed. by A.V. Tarasov. Yuzhno-Sakhalinsk, Sakhalin - Priamurskie vedomosti Publ., 2013. 120 p.

Received: 18 April 2018.

\section{Information about the authors}

Vyacheslav A. Melkiy, Dr. Sc., director, Oil and Gas Technical Institute of Sakhalin State University.

Alexey A. Verkhoturov, Cand. Sc., senior lecturer, Sakhalin State University. 